\title{
Host-Bacterial Symbiosis in Health and Disease
}

\author{
Janet Chow ${ }^{1}$, S. Melanie Lee ${ }^{1}$, Yue Shen ${ }^{1}$, Arya Khosravi ${ }^{1}$, and Sarkis K. Mazmanian \\ Division of Biology, California Institute of Technology, Pasadena, California, USA
}

\begin{abstract}
All animals live in symbiosis. Shaped by eons of co-evolution, host-bacterial associations have developed into prosperous relationships creating mechanisms for mutual benefits to both microbe and host. No better example exists in biology than the astounding numbers of bacteria harbored by the lower gastrointestinal tract of mammals. The mammalian gut represents a complex ecosystem consisting of an extraordinary number of resident commensal bacteria existing in homeostasis with the host's immune system. Most impressive about this relationship may be the concept that the host not only tolerates, but has evolved to require colonization by beneficial microorganisms, known as commensals, for various aspects of immune development and function. The microbiota provides critical signals that promote maturation of immune cells and tissues, leading to protection from infections by pathogens. Gut bacteria also appear to contribute to non-infectious immune disorders such as inflammatory bowel disease and autoimmunity. How the microbiota influences host immune responses is an active area of research with important implications for human health. This review synthesizes emerging findings and concepts that describe the mutualism between the microbiota and mammals, specifically emphasizing the role of gut bacteria in shaping an immune response that mediates the balance between health and disease. Unlocking how beneficial bacteria affect the development of the immune system may lead to novel and natural therapies based on harnessing the immunomodulatory properties of the microbiota.
\end{abstract}

\section{ESTABLISHMENT OF BACTERIAL COMMUNITIES IN THE GASTROINTESTINAL TRACT}

\subsection{Overview of the human gut microbiota}

The human gut harbors up to 100 trillion $\left(10^{14}\right)$ microbes. This is equivalent to $10^{11}-10^{12}$ cells/g colonic content with a biomass of $>1 \mathrm{~kg}$, which is the highest density recorded for any microbial habitat (O'Hara and Shanahan, 2006; Whitman et al., 1998). Our knowledge of the composition of the human gut microbiota was limited to culture-based studies until recent initiatives utilizing high-throughput sequencing and molecular phylogenetic approaches based on sequencing bacterial 16S rRNA genes made available a detailed inventory of the normal human gut microbiota (Eckburg et al., 2005; Palmer et al., 2007; Xu et al., 2007; Zoetendal et al., 2002). Such comprehensive enumeration studies of microbial diversity within the mammalian gut not only improved our understanding of the population composition and the dynamics and ecology of the gut micro-biota but also provided evolutionary insight into the host-microbe mutualism. Although there are at least 55 divisions of bacteria and 13 different divisions of archaea on Earth, the human distal gut microbial community is dominated by members of just two bacterial divisions, Bacteroidetes and Firmicutes, and one member of Archaea, Methanobrevibacter smithii (Eckburg et al., 2005). In contrast to the low levels of deep diversity, the microbial diversity

(C) 2010 Elsevier Inc. All rights reserved.

${ }^{1}$ These authors contributed equally to this work. 
in the mammalian gut exhibits high levels of variation at the level of species and strains. Such extreme fan-like phylogenetic architecture is unique to the mammalian gut microbiota and may reflect a long history of coevolution between microbes and their hosts whereby a few early successful colonizers have maintained an exclusive membership within the gut and have undergone diversification into species and strains (Backhed et al., 2005; Dethlefsen et al., 2007a; Ley et al., 2006).

The gut ecosystem is dynamic. Within a given intestinal habitat, some microbial members may be bona fide "residents" (autochthonous components) that have established commensal status in the gut and persist throughout the lifetime of the host. However, detection of a particular bacterial species from the fecal bacterial community does not necessarily mean that the bacteria are permanent inhabitants of the gut ecosystem. Some microbes found in the gut can be described more accurately as "transient" components (allochthonous members) which originate from ingested food, water, and various aspects of our environment. The difference between the mucosa-associated bacterial communities in the colon and the luminal and fecal bacterial communities can be attributed in part to the different nature of the microbial inhabitance found in different niches within the gut at a given time (Zoetendal et al., 2002). In order to fully understand human biology with respect to the human microbiota, it is crucial to determine which compartment of the microbiota is genuinely autochthonous to the human gut and discover the molecular traits that enable the resident bacterial species to establish and maintain colonization in a highly variable and competitive environment.

\subsection{Molecular determinants of host-bacterial mutualism}

In recent years, researchers studying the human gut microbiota have focused their efforts on identifying members of the community. As a result, we obtained an insight into the ecological and evolutionary pressures shaping the community and how strict the requirements are for the bacteria to gain residence in the gut. However, it is much less straightforward to address qualitative questions as to how certain microbial species can be recognized by the host as commensal organisms and tolerated; what makes resident bacteria resident; and what molecular mechanisms drive gut colonization by commensal organisms. Host-microbe interactions often begin with colonization of mucosal surfaces. These relationships are highly specific, as certain microbial species are found only in particular microenvironments. However, the host and microbial factors that direct establishment and maintenance of a spatially diversified gut microbiota are poorly understood.

One of the most commonly employed experimental approaches to uncovering the intricate cross talk between host and commensal bacteria is the use of gnotobiology. Traditionally performed with rodents, the presence and composition of the microbiota are experimentally manipulated using germ-free host animals. Comparative studies of germ-free and conventionally colonized animals have demonstrated the profound impact of the gut microbiota on the host biology ranging from the mucosal and systemic immunity and morphological integrity of the intestinal epithelial cells (IECs) to the metabolic, absorptive, and endocrine functions (Round and Mazmanian, 2009; Smith et al., 2007). Experiments comparing the gene expression profiles of the intestinal epithelial layer between colonized and germ-free animals have shown direct host responses to intestinal bacteria at the molecular level (Backhed et al., 2004; Hooper et al., 2001, 2003; Salzman et al., 2007; Stappenbeck et al., 2002). Germ-free animals mono-associated with single species of microbes or purified microbial compounds provided a powerful tool for dissecting which microbial signals are required for mutualistic interaction with the host (Bry et al., 1996; Freitas et al., 2005; Hooper et al., 1999; Mazmanian et al., 2005). Another unusual "mutualism factor" was discovered from an elegant model of host-bacterial symbiosis between the marine bacterium Vibrio fischeri and its squid host Euprymna scolopes 
(Nyholm and McFall-Ngai, 2003, 2004). In this partnership, the squid provides a nutrientrich environment for its luminescent symbiont in a specialized light organ. Upon bacterial colonization, the squid undergoes a dramatic morphogenesis which is associated with symbiosis. Interestingly, much of the host morphogenetic program can be induced by conserved components of bacterial cell walls, lipopolysaccharide (LPS), and peptidoglycan (PGN) (Koropatnick et al., 2004). This is an example of host-microbial mutualism driven by microbial factors which are none other than ligands of the innate immune system called pattern recognition receptors (PRRs), also known as microbial-associated molecular patterns (MAMPs). Although MAMPs are commonly linked with pathogenesis in animals, it appears that microbes can use similar molecular signals to mediate beneficial interaction with the host in a context-dependent manner (Cheesman and Guillemin, 2007). In summary, there are many different factors contributing to commensalism between the mammalian host and its gut mutualists and a variety of experimental strategies have been used to elucidate these molecular mechanisms. The rest of this chapter will provide more extensive and detailed examples of molecular mechanisms underlying mutualism between host and microbes leading to establishment of the commensal bacterial communities in the host gut.

\subsubsection{Polysaccharide utilization and host-microbe interaction shaping the gut} microbiota-Bacteroides thetaiotaomicron is one of the most extensively studied symbionts of the human gut. One of the first evidences of gut microbiota playing an active role in host biology was demonstrated by the pioneering work of Hooper et al. (2001), using germ-free mice mono-associated with $B$. thetaiotaomicron and profiling global host transcriptional responses with DNA microarray. Host genes that were upregulated upon $B$. thetaiotaomicron colonization included decay-accelerating factor (DAF), an inhibitor of complement-mediated cytolysis; complement reactive protein (CRP)-ductin, a putative receptor for intestinal trefoil factors that facilitate repair of damaged epithelium; and Sprr2a, a member of the family of small proline-rich proteins known to participate in cutaneous barrier function. Together, these genes demonstrate that commensal bacteria can help fortify the host epithelial barrier. Other host genes affected by mono-association with $B$. thetaiotaomicron were involved with regulation of postnatal maturation (adenosine deaminase), nutrient uptake and metabolism (SGLT-1, colipase, and L-FABP), and processing of angiogenesis (angiogenin-3). This study demonstrated how a single species of commensal organism may restore many of the structural, metabolic, and developmental defects of a previously germ-free host.

When the whole genome of $B$. thetaiotaomicron was sequenced, we gained a much deeper insight into the molecular mechanisms driving this symbiotic relationship (Xu et al., 2003). $B$. thetaiotaomicron contains a 4,779-member proteome that lacks proteins with homology to known adhesins. However, it has evolved 163 paralogs of two outer membrane polysaccharide-binding proteins (SusC and SusD), 226 predicted glycoside hydrolases, and 15 polysacchride lyases. Whole-genome transcriptional profiling of B. thetaiotaomicron disclosed that the bacteria expressed different sets of carbohydrate utilization genes (37 SusC and 16 SusD paralogs were upregulated) when introduced into the germ-free mouse gut compared to when grown in broth consisting of minimal medium with glucose (MM-G) (Sonnenburg et al., 2005). The glycan-foraging behavior of the gut symbiont was further explored by comparing the bacterial gene expression in germ-free mice maintained either on a standard polysaccharide-rich chow diet or on a simple sugar diet devoid of fermentable polysaccharide. Whereas the polysaccharide-rich diet induced upregulation of carbohydrate utilization genes such as xylanases, arabinosidases, and pectate lyases, the glucose and sucrose only diet led to increased expression of a different subset of genes involved in retrieving carbohydrates from mucus glycans such as hexosaminidases, $\alpha$-fucosidases, and a sialidase (Sonnenburg et al., 2005). These genes may also serve to mediate bacterial attachment to mucus glycans to avoid bacterial washout from the gut (Xu and Gordon, 2003; 
Xu et al., 2003). Another noteworthy gene expression change during growth in vitro versus in vivo and with diet manipulation was found in the capsular polysaccharide synthesis (CPS) loci, indicating that $B$. thetaiotaomicron is able to change its surface carbohydrates presumably as a host immune evasion strategy concurrent with the changing glycan-foraging behavior.

B. thetaiotaomicron tells an elaborate story of host-bacterial mutualism based on nutrient metabolism (Hooper et al., 2002; Martens et al., 2009). The ability to salvage energy from nutrients that are otherwise nondigestible by the host provides an evolutionary driving force for the bacteria to maintain residency in the host intestine. Although it lacks adhesive organelles, B. thetaiotaomicron can attach itself to nutrient scaffolds (food particles, mucus layer, and exfoliated epithelial cells; Sonnenburg et al., 2004, 2005) mediated by its repertoire of outer membrane glycan-binding proteins (Backhed et al., 2005). Due to its flexible glycan-foraging ability, B. thetaiotaomicron imparts stability to the gut ecosystem by turning to host polysaccharides when dietary polysaccharides become scarce. This highly successful human gut symbiont has evolved an elaborate and sizable genome that can mobilize functionally diverse adaptive responses to changing nutrient environment and thus guarantee a permanent and mutualistic association with its host.

1.2.2. Role of host immunity in shaping the gut microbiota-Commensal bacterial colonization of the host digestive tract has been shown to induce expression of a number of genes (Bry et al., 1996; Hooper et al., 2001). One of the strategies used by commensal bacteria to maintain a favorable environment and to influence gut microbial ecology at the detriment of other competing and often pathogenic bacteria is inducing and modulating host innate immunity (Kelly et al., 2005). One example is the induction of antimicrobial proteins including angiogenin-4 (Ang4) (Hooper et al., 2003) and the C-type lectin RegIII $\gamma$ (Cash et al., 2006) during the period of weaning or when germ-free mice are mono-associated with $B$. thetaiotaomicron. Ang4 is a novel class of antimicrobial peptides secreted from Paneth cells and has microbicidal effects against several Gram-positive pathogens while leaving $B$.

thetaiotaomicron and another Gram-negative commensal, Escherichia coli K12, unaffected. RegIII $\gamma$ also has antimicrobial properties against Gram-positive pathogens while keeping Gram-negative commensals intact. Unlike other members of the defensin family secreted from Paneth cells where the defensin mRNA levels are similar in the intestines of germ-free and conventionally raised mice, Ang4 and RegIII $\gamma$ expression is sharply induced by $B$. thetaiotaomicron colonization of previously germ-free animals. Weaning is associated with a dramatic change in the composition of the gut microbiota and coincidentally both Ang4 and RegIII $\gamma$ expression levels are upregulated in conventionally raised mice during the weaning period. Together, Ang4 and RegIII $\gamma$ appear to be host factors specifically regulated by commensal organisms to help shape the composition of the adult gut microbiota.

Commensal bacteria of the gut frequently come in contact with the host innate immune system and often cross the epithelial barrier during the sampling of luminal contents by dendritic cells (Macpherson and Harris, 2004). When laden with commensal bacteria, dendritic cells traffic to local mesenteric lymph nodes, where they activate cells of the adaptive immune system and induce secretion of protective $\operatorname{IgA}$ antibodies that coat luminal microbes and prevent them from breaching the epithelium. In contrast, dendritic cells carrying pathogens travel throughout the body and elicit systemic immune responses (Macpherson and Uhr, 2004; Macpherson et al., 2000, 2001). The bacterial signals that give rise to these different dendritic cell behaviors are not known but since heat-killed indigenous bacteria do not elicit this behavior, MAMPs are not likely to be involved in distinguishing between commensal and pathogenic bacteria (Macpherson and Uhr, 2004). 
Using an experimental gnotobiotic animal model harboring genetic immune deficiency, Peterson et al. (2007) investigated the role of IgA in establishing and maintaining a noninflammatory host-microbial relationship. A model symbiont $B$. thetaiotaomicron was introduced into germ-free recombination-activating gene-1-deficient $\left(\operatorname{Ragl}^{-/-}\right)$mice or germ-free $\mathrm{Ragl}^{-1-}$ mice harboring B. thetaiotaomicron-primed IgA-producing hybridoma cells. The presence of IgA reduced intestinal proinflammatory signaling as well as bacterial epitope expression. In another study, mice deficient in activation-induced cytidine deaminase (AID), an essential enzyme for immunoglobulin class switching and somatic hypermutation, showed significant change in the composition of the gut microbiota wherein the segmented filamentous bacteria (SFB) greatly expanded (Suzuki et al., 2004). This dysregulation was recovered by the presence of normal hyper-mutated IgA. These studies suggest that IgA plays a critical role in mediating tolerance in the gut, regulating the gut bacterial composition, and maintaining intestinal homeostasis between host and microbe.

1.2.3. Mucosal surface colonization by commensal bacteria-The mucosal surface of the mammalian distal gut provides a vast surface area where gut microbes come in contact with the host. Understanding the host-microbe interaction at the mucosal surface is fundamental to uncovering colonization mechanisms of commensal bacteria in the gut. However, due to the diverse nature of the gut resident bacteria and the environmental complexity found on the gut mucosal surface, it is highly unlikely that all commensal bacteria colonize the mucus layer through the same mechanism. Moreover, studying the interactions between host and bacteria through the thickness of the mucus layer in vivo has proven to be a formidable task. Our current understanding of how certain bacteria interact within the mucus layer is mainly limited to in vitro bacterial mucin-binding studies which may not recapitulate inside the host intestinal tract.

The mucus gel layer of the large intestine is a dense matrix of polysaccharides (and proteins) derived mainly from the goblet cell lineage of the epithelium. Its thickness and mucin composition vary along the length of the gut (Matsuo et al., 1997). Mucins are highmolecular-weight glyco-proteins characterized by extended serine, threonine, and prolinerich domains in the protein core, which are sites of extensive O-linked glyco-sylation with oligosaccharides (Lievin-Le Moal and Servin, 2006). Traditionally, the mucus gel layer is considered a buffer between the highly immunogenic luminal contents (commensals and pathogens alike) and the host epithelial layer serving to protect both the host and the gut bacteria (Deplancke and Gaskins, 2001). On the contrary, the mucus layer can represent a habitat and source of nutrients for the bacterial communities that colonize mucosal surfaces (Sonnenburg et al., 2004). The principal components of mucus include the large, complex mucin, a variety of smaller proteins and glycoproteins, and lipids and glycolipids secreted by epithelial cells, all of which can provide an excellent source of nutrients and energy for bacterial growth and colonization. The ability of mucus to support the growth of bacteria is evident from numerous in vitro studies in which bacteria have been shown to grow readily in mucus preparations (Jonsson et al., 2001; McCormick et al., 1988). Using a streptomycintreated mouse model, Chang et al. (2004) described several mucus-derived sugars as major carbon sources required for $E$. coli colonization of the gut. Initially, whole-genome transcriptional profiling of $E$. coli strain MG1655 during growth ex vivo on cecal mucus was conducted. Several nutritional genes corresponding to catabolic pathways for nutrients found in mucus were induced. Each pathway was systematically knocked out and mutants were tested for fitness in mouse intestinal colonization. Competitive colonization between wildtype MG1655 and isogenic mutants that lack the ability to catabolize various nutrients confirmed that carbohydrate catabolism plays a dominant role in the initiation and maintenance of $E$. coli colonization of the mouse intestine (Chang et al., 2004). Nutrient availability within the colon mucus layer creates an attractive ecological niche for bacteria and thus provides at least one likely mechanism of gut colonization by commensal bacteria. 
Physical and biochemical analysis of mouse colonic mucus revealed two distinct layers, an inner adherent layer that is firmly adherent to the intestinal mucosa and an outer layer that can be washed off with minimal rinsing (Johansson et al., 2008). Both layers are largely formed by MUC2, a major secretory mucin in humans and mice (Allen et al., 1998), and their protein compositions are identical. However, visual analysis by fluorescence in situ hybridization using a universal probe against bacteria reveals the outer layer is heavily colonized with bacteria while the inner layer is virtually sterile (Johansson et al., 2008). This two-layer structure may reconcile the seemingly contrasting functional roles of the colon mucus layer - the loose outer layer seems to provide an ideal habitat for the commensal bacteria while the inner firmly attached mucus layer forms a specialized physical barrier between the commensal bacteria and the host tissue.

Analysis of carbohydrate structures along the length of the gastrointestinal tract of two humans showed that although their mucin-associated glycans were diverse, their regionspecific glycosylation patterns were well conserved (Robbe et al., 2003). These

glycoproteins and mucoproteins on the mucosal surface of the host gut can serve as receptor sites for attachment and adherence by commensal bacteria (Baranov and Hammarstrom, 2004; Granato et al., 2004). High diversity among the glycans with conserved spatial patterns found on the gut mucosal surface strongly suggests a mechanism of host-driven (perhaps as a result of bacteria modulating the host) regulation of gut microbial community composition by directing members of the microbiota to distinct host niches by serving as nutrient sources or docking sites for these organisms.

\section{DEVELOPMENT OF THE IMMUNE SYSTEM BY COMMENSAL MICROBIOTA}

\subsection{Overview of the mucosal immune system}

Mammalian success depends on the ability to actively clear or contain anything that is detected as infectious nonself. Therefore, the systemic immune system evolved with a very simple goal: to keep internal compartments free of microbial agents. However, within the mammalian gastrointestinal tract, where an astonishing 100 trillion microbes establish residence, a different set of guidelines dictate the function of the mucosal immune system. Here the greatest benefit (and thus success) of the host depends not on sterility, but rather on maintenance of the symbiotic relationship between the host and the intestinal microbiota. Proper development, maturation, and function of the mammalian gastrointestinal track are dependent on contributions by the commensal flora. Germ-free animals that have been raised in the complete absence of microbial exposure present with undeveloped tissue architecture, deficiency in nutrient and vitamin absorption, as well as significant susceptibility to gastrointestinal infection (Dethlefsen et al., 2007; Smith et al., 2007). The benefits imparted by the intestinal microbiota are not limited to the gut as studies have also shown the contribution of these microorganisms toward systemic immune development in addition to neural and metabolic function (Bäckhed et al., 2007; Vijay-Kumar et al., 2010). With multiple aspects of host development and health relying so heavily on the microbiota, it is critical that a system is in place that is able to actively maintain this mutualistic partnership. This responsibility falls in the hands of the mucosal immune system.

While the systemic immune system is designed to react in almost an automatic fashion to any microbial agent it detects, the mucosal immune system must be more tentative in its response so as to preserve the critical partnership with the gut bacteria. However, the presence of this large microbial mass, in such proximity to host tissue, poses a potential and serious threat of infection. Additionally, there is always the risk of infection by acquired, noncommensal gastrointestinal pathogens. Therefore, the challenge to the mucosal immune 
system is to selectively and actively tolerate the gut microbiota during steady-state conditions (when there is a low threat of infection) while being able to mount an appropriate inflammatory response during an incidence of disease or infection. Similarly, it is to the benefit of the microbiota to avoid initiating an inflammatory response in order to maintain its nutrient-rich niche. However, once the microbiota is under immune attack, a more virulent or pathogenic profile may provide certain microbial species with a greater chance of success. The mammalian host and intestinal microbiota, in effect, are establishing a cooperative system that exists only as long as the individual costs for maintaining the collaboration are lower than the benefits received.

\subsection{The mucosal immune system and microbiota form a cooperative system}

A cooperative system consists of two or more players who each pay a cost so that the other player can receive a benefit (Nowak, 2006). The decision to cooperate depends on multiple factors including the type of relationship between the players, the cost versus benefit ratio, and the option of exacting an equal or greater benefit through an alternative source (Dethlefsen et al., 2007; Foster and Wenseleers, 2006). Game theory, a field of applied mathematics, analyzes such standoffs to provide strategies, in a given scenario, that will predict the greatest success for individual players. Within this field, several cooperative systems have been described that are defined by the type of relationship linking the players and the conditions by which cooperation is maintained. Of these systems, the one that most resembles the mammalian-microbial symbiosis is the generous tit-for-tat cooperation system (Nowak, 2006; Perru, 2006). Within this system, two unrelated players form a collaborative alliance to exact a mutual benefit, until one player breaks the trust leading to dissolution of the cooperative system. In the case of intestinal microbiota and mucosal immune system, both parties work to actively maintain tolerance, thus allowing for the benefits of the mutualistic partnership to be realized. This collaboration comes to an end, however, once there is a threat of disease (caused either by aberrant immune activation or infection) where now the costs of maintaining the cooperative system are greater than the benefits received. In a generous tit-for-tat system, as opposed to a tit-for-tat system, mechanisms exist to allow for one party to forgive another party (up to an extent) for "accidental" defection, thus protecting against the loss of cooperation for minor threats (Edwards, 2009). By ascribing the generous tit-for-tat system to mucosal immune system and intestinal microbiota, we wish to highlight the differences in the goals between the mucosal and systemic immune system, as well as provide insight into how this cooperative system is maintained over time, despite episodes of defection by both party members.

2.2.1. Immune plasticity is necessary to maintain cooperation over time-One should be able to appreciate the multiple mechanisms that have evolved, by both the host and the microbiota, to maintain or suspend their mutualistic partnership. This wide arsenal of toleragenic and inflammatory mediators is necessary as the decision to cooperate or defect is under continuous deliberation by both parties, where the costs of maintaining such an alliance are assessed. During incidences of disease, which inflate the costs of cooperation such that individual (host or microbial) fitness is threatened, a pause is placed on the partnership while various mediators (host and microbial) collaborate to reestablish intestinal homeostasis. This back and forth between tolerance and immunity, cooperation and defection, implies mechanisms of plasticity within the host and microbial response are necessary for protection from disease as well as maintenance of the cooperative system over time (Edwards, 2009; Ulvestad, 2009; van Baalen, 1998). Accordingly, mathematical models of host-microbial interactions demonstrate that conditions where players are allowed to alter their actions, in response to one another, promote the evolution of commensalism, as compared to conditions where actions are fixed (Taylor et al., 2006). Applying this concept to the host, plasticity in immune development can be viewed as a mechanism of negotiating 
alliance between the host and the microbiota, in conditions of steady state and disease, allowing for the maintenance of a mutualism over time that is critical to both parties.

Several recent reports have shown the ability of various $\mathrm{T}$ cell sub-populations to redifferentiate into cells that differ in cytokine expression and functional profile. One of the earliest of these studies demonstrated that T helper 17 (Th17) cells, differentiated in vitro, require constitutive TGF- $\beta$ signaling to maintain IL-17F and IL-17A cytokine expression (Lee et al., 2009). Upon cessation of TGF- $\beta$ stimulation, a proportion of these cells presented with diminished expression of IL-17F, and to a lesser extent IL-17A, which was compensated by a rise in IFN- $\gamma$ production. These ex-IL-17, pro-IFN- $\gamma$ cells were shown to be equally inflammatory in the T cell transfer model of colitis, as compared to cells that retained IL-17 expression. More recently, conversion of Th2 cells into GATA3+T-bet+ as well as IL-4+IFN- $\gamma+$ cells was observed following challenge by lymphocytic choriomeningitis virus (Hegazy et al., 2010). This conversion of Th2 cells, which required antigen presentation and IL-12 cytokine stimulation, into Th1Th2 hybrid cells allowed for viral clearance and prevented viral-mediated immunopathology. These two examples demonstrate the ability of effector $\mathrm{T}$ cells to alter their expression profile, possibly to tailor a specific response to a particular microbial agent.

In addition to $\mathrm{T}$ effector cells, $\mathrm{T}$ regulatory cells have been recently shown to adopt a proinflammatory profile, implicating the need to establish an immunogenic response to an agent once tolerated. Zhou et al. (2009) developed a murine model to study the stability of Foxp3 expression that would allow concurrent detection of Foxp3 induction and downregulation. This study observed that $20 \%$ of cells isolated from various lymphoid tissues lost Foxp3 expression (termed "exFoxp3" cells) with a proportion of these cells demonstrating similar methylation patterns in the Treg-specific demethylated region (TSDR) as Foxp3 negative cells. These exFoxp3 cells adopted an activated memory phenotype (CD44 $\left.{ }^{\mathrm{hi}}\right)$ as well as the expression of proinflammatory cytokines that were environment-specific. The study additionally demonstrated an increased ratio of exFoxp3 to Foxp3 positive cells during states of inflammatory disease. To explore the functional properties of these cells, BDC2.5 TCR transgenic mice were crossed with Foxp3 reporter mice, allowing for the isolation of exFoxp3 cells with antigen specificity for pancreatic antigens. When these cells were transferred into $\mathrm{T}$ cell deficient nucleotide-binding oligomerization domain (NOD) TCR $\alpha^{-/-}$ mice there was rapid development of islet destruction and diabetes onset indicating an inflammatory function for these cells. Additional evidence of regulatory T cell plasticity was shown by Murai et al. (2009) where a need for IL-10 signaling to maintain Foxp3 expression and regulatory function in the setting of inflammation was demonstrated. The study utilized the $\mathrm{T}$ cell transfer model of colitis where effector $\mathrm{T}$ cells are transferred into a $\mathrm{Rag}^{-/-}$host leading to the onset of inflammatory bowel disease (IBD), whereas cotransfer with Foxp3+ cells protects from disease. However, Foxp3+ cells transferred along with

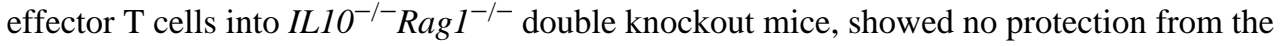
onset of colitis. Additional analysis confirmed that a greater proportion of the transferred regulatory cells into IL-10 deficient hosts lost Foxp3 expression, compared to cells transferred into IL-10 competent mice. This loss of Foxp3 expression was complemented by a gain in IFN- $\gamma$ production. Loss of Foxp3 expression was dependent on the presence of inflammation, as transfer of Tregs alone without T effector cells into IL-10 deficient hosts did not lead to loss of Foxp3 expression. The authors concluded that Foxp3 expression was unstable within an inflammatory setting, but could be maintained by IL-10 stimulation, as provided by CD11b+CD11c+ mucosal dendritic cells. In these two examples, it is shown how $\mathrm{T}$ regulatory cells can, under regulated conditions, lose their toleragenic profile, presumably to contribute to immune eradication of an infectious agent. Although it still remains to be shown that proinflammatory $\mathrm{T}$ cells can be redifferentiated into cells that promote tolerance, the overall ability of $\mathrm{T}$ cells to be reprogrammed into cells with different 
function has been established. And while it is currently speculation, one could appreciate the value of this flexible immune response to the continuously changing microbial environment in the gut which is regulated by immune cells able to switch promoting tolerance to developing an immunogenic response.

2.2.2. Immune plasticity in response to the microbiota-While direct evidence is currently lacking, it can be inferred that the changes in the immune profile and function of certain $\mathrm{T}$ cell populations are in part driven by alterations in the microbiota. The microbiota has been shown to directly modulate both innate and adaptive immune responses. The immune subsets that are influenced by certain microbes may require continuous stimulation to maintain profile and function. Therefore, loss or alteration of particular microbial communities could then potentially result in a change in immune profile and function among certain immune populations. Mucosal Th17 cells represent one immune subset that may require continuous stimulation by certain microbial species to maintain its cytokine profile. Multiple studies have shown that Th17 cells are largely absent in the small intestine of germ-free mice (Atarashi et al., 2008; Ivanov et al., 2008). The adoption of an IL-17 profile by mucosal $\mathrm{T}$ cells was shown to be in part dependent on intestinal colonization with SFB, a commensal microbe that tightly adheres to the small intestinal epithelium (Ivanov et al., 2009). Mice that are normally colonized, but lack SFB also showed reduced Th17 cells in the small intestine, similar to germ-free animals. However, upon colonization with SFB, these mice developed Th17 cells similar to that of control animals. Additionally, short-term antibiotic treatment that depleted the microbiota resulted in a loss of intestinal Th17 cells, supporting the concept that certain immune cells require continuous stimulation by particular microbes to maintain their functional profile (Ivanov et al., 2008). The change in the Th17 population following intestinal colonization with SFB or antibiotic-mediated reduction of the microbiota indicates plasticity in $\mathrm{T}$ cell response to changes in the microbiota.

In another example, Polysaccharide A (PSA), a capsular polysaccharide expressed by commensal organism Bacteroides fragilis has been shown to modulate both the mucosal and systemic immune system. Mono-colonization with $B$. fragilis induces IL-10 production among intestinal CD4+ $\mathrm{T}$ cells providing protection against colitis (Mazmanian et al., 2008). Even short-term oral exposure to purified PSA is able to promote the toleragenic T cell profile, resulting in protection from autoinflammatory intestinal disease. However, once $B$. fragilis gains systemic exposure, a proinflammatory response is initiated resulting in $\mathrm{T}$ cell driven peritoneal abscess formation (Gibson et al., 1998). The abscess formation appears to be IL-17 dependent and serves as an excellent example of the mucosal immune system's ability to switch between toleragenic and inflammatory response to the same microbial antigen (Chung et al., 2003). Additionally, one could speculate once the threat of systemic infection by $B$. fragilis has subsided, PSA could once again induce an IL-10 profile among mucosal T cells, effectively contributing to the mucosal immune system's switch back from inflammation to cooperation with the microbiota. The ability of antigen-specific $\mathrm{T}$ cells to switch between pro- and anti-inflammatory subtypes is one possible example as to how the mucosal immune system is able to effectively shuffle between the inflammatory and toleragenic immune responses necessary to maintain intestinal homeostasis. Additionally, the microbiota may in part contribute to directing $\mathrm{T}$ cells to adopt the immune profile necessary for maintaining homeostasis. One could then speculate that loss of either the host or microbial components necessary to switch between inflammation and tolerance could enhance susceptibility to immune disorders such as IBD. 


\section{PROINFLAMMATORY RESPONSES OF BACTERIAL-HOST GUT INTERACTIONS}

\subsection{Bacterial induction of proinflammatory responses}

Studies from germ-free animals have provided a great deal of insight on the biological repercussions of bacterial colonization (Falk et al., 1998). These studies of gnotobiology, which involve known colonization of selective microorganisms, have revealed that the microbiota plays a key role in the postnatal development of intestinal immune structures, such as gut-associated lymphoid tissues (GALT) and isolated lymphoid follicles (ILF) (Bouskra et al., 2008; Macpherson and Harris, 2004). Furthermore, the gut microbiota has been shown to affect the development of the adaptive immune response by actively inducing proinflammatory responses.

Th17 cells play an important role in eliminating extracellular pathogens. Th17 cells produce the cytokines IL-17A, IL-17F, and IL-22, which subsequently trigger inflammatory signaling cascades and can lead to the recruitment of innate immune responder cells (Korn et al., 2009). Although Th17 cells are essential for immunity, they have been implicated in many autoimmune diseases, including IBD, arthritis, psoriasis, and experimental autoimmune encephalomyelitis (EAE) highlighting the importance of T cell effector regulation.

During steady state, Th17 cells are most abundant in gut-associated immune tissues. Interestingly, Th17 cells accumulate only in the presence of the intestinal commensal microbiota and are virtually absent in germ-free animals (Atarashi et al., 2008; Chow and Mazmanian, 2009; Ivanov et al., 2008; Niess et al., 2008). Treatment of conventionally colonized animals with selective antibiotics greatly diminished the amount of intestinal Th17 cells (Ivanov et al., 2008). Conversely, upon colonization with a conventional microbiota, germ-free animals acquired intestinal Th17 cells. The composition of the microbiota appears to be important as germ-free animals colonized with a defined cocktail of bacteria (Altered Schaedler Flora) still lacked Th17 cells in the small intestine (Ivanov et al., 2008). Thus, the induction of intestinal Th17 cells is dependent on specific bacterial taxa as opposed to the general presence of bacteria. The precise molecular signaling mechanisms that commensal bacteria employ to induce these Th17 responses still remain to be discovered. It has been proposed that adenosine $5^{\prime}$-triphosphate (ATP), a molecule that is abundantly derived from commensal bacteria may play a role in Th17 cell differentiation by activating a unique subset of lamina propria cells, $\mathrm{CD} 70^{\text {high }} \mathrm{CD} 11 \mathrm{c}^{\text {low }}$ cells (Atarashi et al., 2008). Compared to conventional animals, germ-free mice had greatly reduced concentrations of luminal ATP, and correspondingly, fewer Th17 cells in the lamina propria. Administration of ATP to germ-free animals led to a significant increase in intestinal Th17 cells.

Recent studies by two independent laboratories have identified a unique population of the intestinal microbiota, SFB, that is capable of inducing intestinal Th17 cells and recapitulating the maturation of $\mathrm{T}$ cell responses induced by the complete conventional mouse microbiota (Gaboriau-Routhiau et al., 2009; Ivanov et al., 2009). These nonculturable Gram-positive Clostridia-related species adhere tightly to the surface of IECs. SFB colonization of the murine small intestine of germ-free animals was sufficient to induce lamina propria Th17 cells, which were marked by the production of IL-17 and IL-22 cytokines (Ivanov et al., 2009). Colonization with SFB also correlated with an increase in expression of genes associated with antimicrobial defenses. More importantly, animals colonized with only SFB showed enhanced resistance to infection with the intestinal pathogen Citrobacter rodentium, suggesting a functional role for SFB-induced immune 
responses in mucosal protection. In mice, Th17 immune responses have been shown to mediate protective roles in infections with extracellular and intracellular enteric pathogens such as C. rodentium and Salmonella enterica (Curtis and Way, 2009). Thus, bacteriainduced Th17 responses may provide a mechanism for increased intestinal resistance against pathogens. The repertoire and antigen specificity of these induced Th17 cells, whether specific for microbial compounds and/or self-antigen, will be of interest as Th17 responses have become increasingly implicated in driving autoimmune responses.

Commensal bacteria play a critical role in modulating other responses of the adaptive and innate immune system as well. Colonization of germ-free animals with the human intestinal commensal B. fragilis induced cellular and physical maturation of the immune response that was mediated by a single bacterial polysaccharide molecule (PSA) (Mazmanian et al., 2005). Modulation of the immune system by PSA included the systemic expansion of CD4+ $\mathrm{T}$ cells and the induction of Th1 cytokine production in vitro. A B. fragilis mutant lacking PSA was unable to recapitulate these immunomodulatory activities. Furthermore, the commensal microbiota has been shown to drive the expansion of Th1 cells as well in the colonic lamina propria (Niess et al., 2008). Commensal DNA has been demonstrated to increase the amount of IFN- $\gamma$ and IL-17 producing T effector cells by signaling through TLR9 (Hall et al., 2008). In $T L R 9^{-1-}$ animals and antibiotic-treated wild-type animals, oral infection with the parasite Encephalitozoon cuniculi led to an impaired protective immune response that was unable to control parasite burden compared to untreated wild-type animals. Addition of microbial DNA was sufficient to restore immune responses in these animals. TLR-dependent stimulation of host dendritic cells by gut bacteria has also been shown to play a key role in both innate and adaptive immunity to Toxoplasma gondii (Benson et al., 2009). Taken together, these studies suggest that intestinal commensal bacteria may function as molecular adjuvants for mounting immune responses toward infectious microorganisms. Commensal bacteria also appear to be involved in the generation of IL-22-producing NKp46+ cells (Sanos et al., 2009). Furthermore, signaling through TLRs by commensal bacteria seems to be critical for maintaining intestinal epithelial homeostasis and protection from intestinal injury (Rakoff-Nahoum et al., 2004). Thus, host communication with commensal bacteria plays a crucial role in priming and expanding basal levels of innate and adaptive immune activation.

\subsection{Imbalances in host-microbial interactions}

Interactions between the mammalian host and the intestinal microbiota require a delicate balance that must be actively maintained by both host and microbe to achieve a healthy steady state (Pamer, 2007; Round and Mazmanian, 2009; Sansonetti, 2004). Regulatory mechanisms exist to control bacterial colonization of the gut, while simultaneously preventing the immune system from reacting against innocuous microbial antigens. As MAMPs are found ubiquitously on both pathogenic and commensal bacteria, it is crucial for the immune system to account for these important subtleties. When this equilibrium is disrupted, inflammation can ensue potentially leading to disease.

The mammalian gut has evolved numerous physical and molecular mechanisms for maintaining homeostasis with commensal organisms. The intestinal surface constitutes an area of approximately $100 \mathrm{~m}^{2}$ that is continuously exposed to mucosal and luminal microbes (Artis, 2008). A single layer of IECs serves as an essential barrier between luminal contents and underlying host tissues. Tight junctions formed between IECs prevent bacteria from penetrating tissues. A rich glycocalyx layer of mucus and other glycoproteins further hinder bacterial attachment and invasion to host cells. Paneth cells and enterocytes in the gut secrete antimicrobial peptides, such as defensins, cathelicidins, and angiogenins which generally function by forming pores in bacterial cell walls. These molecules are released in a concentration gradient manner that can modulate the spatial colonization of gut bacteria. 
While some classes of antimicrobial peptides are constitutively expressed, others are regulated by bacterial signaling through PRRs. Peristalsis of the intestinal tract, rapid turnover of IECs, and secretion of IgA serve to confine the majority of the microbiota to the luminal compartment as well. It has also been suggested that commensal organisms of the microbiota may preferably colonize the lumen of the intestine instead of the mucosal layer to maintain a safe distance from host tissues, whereas enteric pathogens may overstep these boundaries (Hooper, 2009). Spatial localization of PRRs, such as toll-like receptors (TLRs) and NOD proteins, in the gut help prevent inadvertent activation of the innate immune system by the microbiota. In the small intestine of mice, expression of TLR4 and possibly NOD receptors may occur primarily in the bottom of intestinal crypts, allowing innate immune activation only when bacteria have breached host borders (Hornef et al., 2002; Ortega-Cava et al., 2003).

Furthermore, commensal bacteria may actively employ mechanisms to maintain equilibrium with host cells. Modulating expression of immunodominant epitopes may be one method used by symbiotic bacteria to avoid immune recognition and to stably colonize the gut (Comstock and Coyne, 2003; Krinos et al., 2001). Genomic sequencing of several human gut-associated Bacteroides species has shown the presence of many genetic loci for the purpose of generating diversity in the polysaccharide coat (Cerdeno-Tarraga et al., 2005).

Host genetics factors play an important role in determining whether commensal bacteria will be perceived as pathogenic or not, and in maintaining a "healthy" microbiota. Studies of Helicobacter hepaticus, a Gram-negative murine bacterium, have provided insight on host immune responses that lead to disease. H. hepaticus sustains long-term colonization of the lower gastrointestinal tract of wild-type mice in the absence of disease. However, $H$. hepaticus appears to be an intestinal pathobiont-essentially a symbiont that is able to promote pathology only under specific genetic or environmental host conditions (Mazmanian et al., 2008; Round and Mazmanian, 2009). In immunocompromised animals such as $\mathrm{Ragl}^{-/-}$or $I \mathrm{~L}-1 \mathrm{O}^{-/-}$mice that lack proper immune regulation and consequently elicit exaggerated proinflammatory responses, $H$. hepaticus is capable of promoting chronic pathology in animal models of colon cancer and experimental colitis (Erdman et al., 2009; Kullberg et al., 1998, 2001). H. hepaticus antigen-specific CD4+ Th1 clones transferred into H. hepaticus-infected $\mathrm{Rag}^{-/-}$animals were capable of transferring disease, indicating that aberrant $\mathrm{T}$ cell populations targeting the microbiota may be sufficient to trigger colitis (Kullberg et al., 2003). Furthermore, H. hepaticus-induced colon disease is strikingly similar to human disease, providing a useful tool for the investigation of human intestinal disorders such as IBD and colon cancer.

In some cases, animals with genetic deficiencies may select for a pathogenic microbiota that can elicit inflammation in the host and even cause disease when transferred to other animals (Garrett et al., 2007). In these studies, $T$-bet ${ }^{-1-}$ animals lacking an adaptive immune system developed spontaneous colitis. Initial work had identified T-bet as mainly functioning in the development of Th1 cells; however, T-bet has recently been implicated in directing proinflammatory roles in the innate immune system as well. Intestinal disease in these animals progressively worsens into colonic dysplasia and rectal adenocarcinoma, implicating a strong role for T-bet in maintaining proper host-commensal relationships (Garrett et al., 2009). Moreover, cohousing $T$-bet ${ }^{-1-}$ animals with wild-type animals resulted in the transfer of disease, indicating the presence of a colitogenic microbiota that is communicable. Antibiotic treatment of animals cured intestinal inflammation indicating the role of the microbiota in driving disease.

Antimicrobial peptides appear to also be important in regulating the composition of the microbiota. Dysregulation of antimicrobial peptides in Drosophila melanogaster gut led to 
host mortality, caused by the outgrowth of a pathogenic microbiota dominated primarily by a single gut microbe (Ryu et al., 2008). Transgenic mice either expressing human $\alpha$-defensin (DEFA5) or lacking an enzyme required for functional mouse $\alpha$-defensin molecules exhibited significant differences in their microbiota compositions, despite having similar numbers of total bacteria (Salzman et al., 2010). DEFA5-expressing mice had a sharp reduction in SFB and correspondingly, fewer Th17 cells in the lamina propria.

In addition, signaling through IECs plays a critical role in gut homeo-stasis and intestinal inflammation. In mice deficient in the single immunoglobulin IL-1 receptor-related molecule (SIGIRR), which acts as a negative regulator for Toll-IL-1R signaling, increases in cell proliferation and inflammatory responses that were commensal-dependent were observed (Xiao et al., 2007). Altogether, these studies highlight the profound implications genetic disorders can have on host-commensal mutualisms.

\subsection{Implications for human IBD}

IBDs, which include Crohn's disease and ulcerative colitis, are chronic relapsing disorders of the gastrointestinal tract. IBD results in a wide range of clinical outcomes in affected individuals. The disease is, generally, thought to be mediated by an overt $\mathrm{T}$ cell inflammatory response that is perpetuated by stimulation from microbial antigens. Current animal models of IBD suggest that pathogenesis is driven by a variety of interacting factors, including host genetic and immune status, the gut microbiota, and environmental triggers (Packey and Sartor, 2008).

Commensal bacteria of the microbiota have been strongly implemented in the initiation and progression of IBD. Patients with IBD show higher serological and T cell responses to enteric microbial antigens and respond favorably to antibiotic treatment (Macpherson et al., 1996; Sartor, 2004). In Crohn's disease, inflammation occurs primarily in intestinal segments with the highest concentrations of bacteria, and increased levels of mucosalassociated bacteria have been observed (Swidsinski et al., 2002). In models of experimental colitis, inflammation generally does not ensue when animals are placed under germ-free conditions. Polymorphisms of genes encoding bacterial receptors have been associated with Crohn's disease as well.

Despite the important contribution of the microbiota in IBD, only one bacterial species has been identified as being strongly correlated with disease. In patients with Crohn's disease, the ileal mucosa is abnormally colonized by adherent-invasive $E$. coli (AIEC), which adhere to and invade IECs. Primary ileal enterocytes isolated from patients with Crohn's disease showed greater AIEC adherence compared to cells from healthy controls (Barnich et al., 2007). Expression of CEACAM6, which serves as a binding receptor for AIEC adherence, was also shown to be abnormal in epithelial cells of IBD patients. In transgenic mice expressing human CEACAM, colonization with AIEC led to mucosal inflammation and colitis (Carvalho et al., 2009).

IBD may be caused in part by overall changes in the development or composition of the intestinal microbiota, known as dysbiosis (Kinross et al., 2008; Ley et al., 2007; Mazmanian et al., 2008). Currently, it remains unknown whether dysbiosis of the gut microbiota is a result of IBD or the cause of inflammation. These changes in the microbial community may result in a reduction of protective commensal organisms and/or an increase in potentially aggressive pathobionts. Clinical data show that in IBD patients with underlying genetic mutations, inflammation is directed toward specific commensal organisms of the microbiota, such as Clostridium and Enterococcus species which are ubiquitously found in the mammalian gut. Thus, symbiotic microbes which are, generally, perceived as innocuous by hosts become sources of inflammatory antigen. Culture-independent rRNA sequence 
analysis of intestinal tissue samples from patients with and without IBD revealed a striking difference between the microbiota of healthy and IBD patients. Temporal stability and diversity of the gut microbiota composition in IBD patients were revealed to be significantly decreased compared to non-IBD controls (Scanlan et al., 2006). Interestingly, the microbiotas of IBD patients were marked by a reduction in commensal bacteria, particular in members of the phyla Firmicutes and Bacteroidetes, and exhibited a concomitant increase in Proteobacteria and Actinobacteria (Frank et al., 2007). A reduction in Clostridia species and Bacteroides species in IBD patients may have profound effects on intestinal health, as these species produce butyrate and other short-chain fatty acids (SCFAs) that are important in enhancing epithelial barrier integrity and modulating intestinal immune system responses. Correspondingly, a reduction in SCFAs has been noted in patients with IBD and increased dietary intake of SCFAs seems to ameliorate colitis symptoms (Harig et al., 1989; Kanauchi et al., 2002; Treem et al., 1994).

The concept of dysbiosis is also supported by animal models of obesity (Turnbaugh et al., 2006). In these studies, transferring the microbiota from obese mice to nonobese mice led to an increase in mean body fat of recipient animals, suggesting that disturbances in the microbiota can directly affect physiological health. With the development of large-scale metagenomic sequencing technologies, future studies will uncover the precise role the microbiota play during initiation and progression of IBD (Turnbaugh et al., 2007). Gnotobiotic studies of germ-free animals will be instrumental in identifying functional effects of colonization with specific species.

In addition, genetic factors in the host can contribute to susceptibility to disease. This has been demonstrated by familial aggregation of IBD and the increased concordance for IBD in monozygotic twins. Mutations in Nod2/Card15 have been positively correlated with Crohn's disease patients compared to healthy controls (Hampe et al., 2001; Hugot et al., 2001; Ogura et al., 2001). Nod2 plays a role in sensing intracellular bacteria and functions to stimulate $\alpha$ defensin production in Paneth cells. Incidentally, in Crohn's disease patients with Nod2 mutations, a reduction in $\alpha$-defensin has been observed (Wehkamp et al., 2005). Mutations in other innate immune proteins that respond to microbial antigens have further been identified-TLR1, 2, 4, and 6; ATG16L1, which is involved in the autophagosome pathway; and NCF4, which mediates bactericidal activities in phagocytes (Franchimont et al., 2004; Hampe et al., 2007; Pierik et al., 2006; Rioux et al., 2007). Intestinal homeostasis requires proper bacterial recognition and elimination of organisms that invade host tissues. Defects in these critical processes can lead to increased microbial antigen exposure and subsequent chronic inflammation. Variations in genes related to $\mathrm{T}$ cell immunity have also been implicated. A genome-wide association study identified a significant association between Crohn's disease and the $I L-23 R$ gene (Duerr et al., 2006). Polymorphisms in $I L-23 R$ were strongly correlated with either increased resistance or susceptibility to IBD. $I L-23 R$ variants associated with increased susceptibility correlated strongly with higher serum levels of IL-22, suggesting a role for Th17 cell function (Schmechel et al., 2008). In an experimental model of colitis, treatment of animals with monoclonal antibody against IL-23p19 alleviated inflammation and induced apoptosis of Th17 cells, highlighting the importance of these findings (Elson et al., 2007).

\section{COMMENSALS CONTRIBUTE TO HOST-MICROBIAL HOMEOSTASIS BY ACTIVELY SUPPRESSING INFLAMMATORY RESPONSES DURING HEALTH AND DISEASE}

As discussed previously, large amounts of commensal bacteria reside in close proximity to the host mucosal surfaces. Although the majority of the commensal community exhibits 
beneficial relationships with the host, some members of the community have the potential to trigger pathogenic inflammatory responses under certain conditions. Since certain components of the commensals still possess pathogenic activity, the question becomes how the symbiotic relationships between commensals and their hosts are maintained during steady state without eliciting harmful inflammation that may result in tissue damage.

In early sections, we discussed various host mechanisms that contribute to the hostmicrobial homeostasis. Such mechanisms include the secretion of a thick mucus layer by goblet cells in the intestine, the production of antimicrobial peptides and IgA by Paneth cells and B cells, respectively, all of which restrict the microbiota from directly contacting host tissues and prevent the penetration of commensals across the epithelial barrier which may further induce host inflammatory responses. However, immunological ignorance of the microbiota is just one side of the story. The constant interaction between commensals and the epithelium is inevitable because stable colonization of the microbiota requires close contact of bacteria with mucosal surfaces. Moreover, PRRs, such as TLRs and NOD family proteins, are expressed on epithelial cells to specifically monitor the microbial components in the environment and are ready to trigger downstream inflammatory responses once bound with MAMPs. Therefore, there must exist other mechanisms to dampen the constant inflammation that the microbiota may induce in healthy hosts. In recent years, an increasing amount of evidence has suggested that commensals actually have evolved different ways to actively suppress inflammation, not only during steady state, but also during pathogenic states.

\subsection{Downregulation of innate immunity}

PRRs, such as TLRs, play essential roles in innate immunity in response to microbial agents. They are surface or intracellular signaling receptors that are able to recognize microbespecific molecules and trigger intracellular signaling cascades, which eventually lead to the activation of several transcription factors (e.g., NF- $\mathrm{BB}, \mathrm{AP}-1, \mathrm{IRF}-3,-7$ ) that drive the transcription of genes involved in proinflammatory responses (Takeda and Akira, 2005). Recently, several studies have demonstrated that commensal organisms may target and inhibit NF- $\mathrm{KB}$ activation to suppress inflammation. By analyzing the composition of the intestinal microbiota of Crohn's disease patients, Sokol et al. (2008) identified Faecalibacterium prausnitzii, which is greatly reduced in Crohn's disease patients, as an anti-inflammatory commensal bacterium in the gut by showing that the supernatant of $F$. prausnitzii inhibited NF- $\kappa \mathrm{B}$ activation in a human IEC line and suppressed proinflammatory cytokine production both in vitro and in a mouse colitis model. However, the molecular mechanism by which this occurs remains to be found. It is well-known that activation of $\mathrm{NF}-\kappa \mathrm{B}$ is highly regulated by its inhibitor, IкB. Phosphorylation, ubiquitination, and

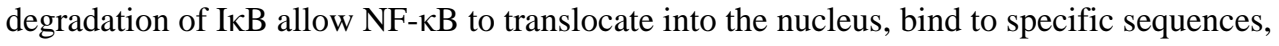
and induce transcription of target genes (Karin and Ben-Neriah, 2000). An in vitro study by Neish et al. (2000) showed nonpathogenic Salmonella typhimurium could inhibit IKB $\alpha$ degradation and in turn prevent NF- $\kappa \mathrm{B}$ from entering the nucleus in human epithelial cells so as to reduce the NF- $\mathrm{KB}$-mediated inflammatory response. Furthermore, a prevalent commensal bacterium of the human intestinal microbiota, B. thetaiotaomicron, was demonstrated to attenuate proinflammatory cytokine production from epithelial cells in vitro and prevent pathology in epithelial tissues in vivo. The authors discovered that the mechanism underlying this anti-inflammatory activity involved $B$. thetaiotaomicron facilitating the nuclear export of NF- $\mathrm{KB}$ subunit RelA in a PPAR $\gamma$-dependent manner, which largely decreased the transcription of NF- $\mathrm{BB}$-mediated proinflammatory genes (Kelly et al., 2004). It is worth noting that some pathogens have also evolved a similar mechanism to escape attack from the proinflammatory response. This may lead to the question whether commensal bacteria actually help the evasion of pathogens by down-regulating NF-кB. 
However, this does not appear to be the case as colonization by beneficial bacteria does not result in immunodeficiency. Thus, the immune-suppression mechanism of commensals must differ from that of pathogens in that it must keep basal inflammation at a low level while also allowing the host immune system to retain its ability to elicit strong proinflammatory responses against pathogens. To unveil the difference, detailed comparison between commensals and pathogens in their abilities to interfere with NF- $\mathrm{kB}$ activation may be helpful. More importantly, it may bring up new targets for treating inflammatory diseases.

On the other hand, although TLR/NOD signaling typically results in proinflammatory responses toward microbes, there are studies suggesting that they might also play important roles in sensing molecules derived from commensals to elicit responses counteracting the inflammation. For example, Lai et al. found that after skin injury, Staphylococcus epidermidis, a member of the skin microbiota, could suppress the release of proinflammatory cytokines in keratinocytes and inhibit tissue inflammation in vivo. The bacterial molecule, LTA, which is responsible for this anti-inflammatory activity, was discovered to signal through TLR2 to induce the expression of TRAF1, a negative regulator of TLR3-mediated NF- $\kappa$ B activation in keratinocytes (Lai et al., 2009). However, this study and others as well have shown that LTA actually induces proinflammatory responses in other cell types, such as macrophages, monocytes (Timmerman et al., 1993), and mast cells (Yoshioka et al., 2007). This brings up the question as to how TLRs differentiate signals from commensals and pathogens to initiate signaling cascades with seemingly opposite consequences. One explanation proposed from this study was that TLRs may function differently depending on the cell location or the proximity to microbes. Therefore, since keratinocytes are constantly exposed to the skin microbiota and have a greater chance of interacting with commensal-derived molecules, their TLRs may act as an anti-inflammatory mediator to balance basal inflammation.

In addition to directly targeting TLR-mediated signaling to suppress inflammation in cells that are in close contact with the microbiota, commensals have also developed ways to modulate innate immune responses of other cell types, such as neutrophils. Maslowski et al. (2009) found that SCFAs, which are produced after fermentation of dietary fiber by intestinal commensals, could interact with G-protein-coupled receptor 43 (GPR43)expressing neutrophils to attenuate inflammation during experimental colitis, arthritis, and asthma. This is an interesting finding because it connects the diet with the composition of the microbiota and the host immune response, and may explain to some extent the difference in susceptibility to human inflammatory or autoimmune diseases in different areas of the world.

Taken together, the innate immune system of the host, while serving as the early defense mechanism against pathogenic agents, also provides a platform that can be greatly influenced by commensal organisms, in order to maintain host-microbial homeostasis and prevent excessive inflammation during disease.

\subsection{Induction of $\mathrm{T}$ cell-dependent regulatory responses}

As previously mentioned, colonization of commensal organisms has profound influences on the development of the adaptive immune system of the host. Thus, it is very likely commensals may also play a role in shaping the adaptive immune response, thereby contributing to host-microbial homeostasis.

The main and essential force of the adaptive regulation of inflammatory responses is the induction of regulatory $\mathrm{T}$ cells (Tregs). Tregs are marked by the expression of a master transcription factor, Foxp3 (Fontenot et al., 2005). Once differentiated and activated, Tregs downregulate inflammatory responses by secreting anti-inflammatory cytokines (e.g., 
IL-10), suppressing effector T cell responses, and inhibit the activation of dendritic cells or macrophages (Vignali et al., 2008). Recently, a few studies have demonstrated that some commensal bacteria or the molecules derived from them may induce Treg differentiation or release of anti-inflammatory cytokines. For example, O'Mahony et al. (2008) showed that Bifidobacterium infantis-fed mice were protected from pathogenic S. typhimuriumstimulated inflammation by induction of a Treg population. More importantly, adoptive transfer of Tregs induced by $B$. infantis greatly reduced NF- $\mathrm{KB}$ activation in the animal and deletion of these Tregs abolished the inhibition, suggesting these Tregs are both required and sufficient for the anti-inflammatory activity of $B$. infantis. Similarly, an in vitro study showed that $B$. infantis inhibited the production of IL-17 and induced the release of antiinflammatory IL-10 in cultured murine splenocytes stimulated by TGF- $\beta$ and IL- 6 (Tanabe et al., 2008). Another in vivo study revealed that polysaccharide A, a surface molecule of a prominent commensal bacterium of the human gut, $B$. fragilis, can protect animals from both CD4+ CD45Rb ${ }^{\text {high }} \mathrm{T}$ cell transfer and chemical (TNBS)-induced experimental colitis by inducing IL-10 producing CD4+ T cells (Mazmanian et al., 2008). Interestingly, even a pathobiont, such as $H$. hepaticus, can induce a Treg population in healthy hosts to protect against the development of experimental colitis. Adoptive transfer of these Tregs into immunocompromised hosts prevented colitis triggered by $H$. hepaticus infection in an IL-10-dependent manner (Kullberg, 2002). In addition, new evidence has further suggested that Tregs may also serve as helpers to promote IgA production in B cells in order to maintain homeo-stasis between the host and the microbiota (Cong et al., 2009).

$\mathrm{T}$ cell differentiation into various lineages with different effector functions is thought to be directed by the maturation and activation of dendritic cells. Subsequently, a few studies have investigated the influence of commensal organisms on dendritic cell function. Christensen $e t$ al. showed that various Lactobacillus strains differentially modulate dendritic cell maturation and cytokine production. L. reuteri DSM12246 is not only poor at eliciting proinflammatory cytokines, such as IL-12, IL-6, and TNF $\alpha$, but is also able to suppress these cytokines triggered by L. casei $\mathrm{CHCC} 3139$, while producing anti-inflammatory cytokine IL-10 (Christensen et al., 2002). Such phenomenon indicates that regulation between closely related commensal organisms might be a mechanism to limit inflammation toward beneficial bacteria and maintain mutualism with the host. Likewise, Baba et al. tested the effect of eight different commensal bacteria on the maturation of dendritic cells. Although different species induced distinct cytokine production profiles in den-dritic cells, most of them directed dendritic cells to promote suppressive CD4+ $\mathrm{T}$ cell differentiation in vitro (Baba et $a l ., 2008)$. Future experiments will be required to shed light on the cellular mechanisms underlying these observations. Taken together, these studies suggest that dendritic cells may be an important mediator for Treg induction during interaction between commensals and the host adaptive immune system.

One remaining question here is whether the induction of Tregs by commensal bacteria will render the host immunocompromised. If not, how is the immunosuppressive activity of these Tregs regulated? One of the most intriguing hypotheses would be that commensal bacteria induce antigen-specific Tregs, which means that Tregs induced by one specific bacterium would only suppress the inflammatory response toward itself. Such a hypothesis provides a new angle of looking at the influence of the microbiota on the host adaptive immune system, but it also raises another question of how the antigen specificity is achieved, which in itself remains to be discovered.

There is no doubt that commensal organisms actively interact with both the innate and adaptive immune systems to maintain commensalism with the host. Moreover, the ability of commensals to regulate host inflammation may play a critical role during inflammatory diseases, such as IBD. Therefore, a better understanding of the molecular mechanisms 
involved in these processes may greatly advance the development of new therapies for inflammatory diseases.

\section{References}

Allen A, Hutton DA, Pearson JP. The MUC2 gene product: A human intestinal mucin. Int J Biochem Cell Biol. 1998; 30:797-801. [PubMed: 9722984]

Artis D. Epithelial-cell recognition of commensal bacteria and maintenance of immune homeostasis in the gut. Nat Rev Immunol. 2008; 8:411-420. [PubMed: 18469830]

Atarashi K, Nishimura J, Shima T, Umesaki Y, Yamamoto M, Onoue M, Yagita H, Ishii N, Evans R, Honda K, et al. ATP drives lamina propria $\mathrm{T}(\mathrm{H}) 17$ cell differentiation. Nature. 2008; 455:808-812. [PubMed: 18716618]

Baba N, Samson S, Bourdet-Sicard R, Rubio M, Sarfati M. Commensal bacteria trigger a full dendritic cell maturation program that promotes the expansion of non- Tr1 suppressor T cells. J Leukoc Biol. 2008; 84:468-476. [PubMed: 18511576]

Backhed F, Ding H, Wang T, Hooper LV, Koh GY, Nagy A, Semenkovich CF, Gordon JI. The gut microbiota as an environmental factor that regulates fat storage. Proc Natl Acad Sci USA. 2004; 101:15718-15723. [PubMed: 15505215]

Backhed F, Ley RE, Sonnenburg JL, Peterson DA, Gordon JI. Host-bacterial mutualism in the human intestine. Science. 2005; 307:1915-1920. [PubMed: 15790844]

Bäckhed F, Manchester JK, Semenkovich CF, Gordon JI. Mechanisms underlying the resistance to diet-induced obesity in germ-free mice. Proc Natl Acad Sci USA. 2007; 104:979-984. [PubMed: 17210919]

Baranov V, Hammarstrom S. Carcinoembryonic antigen (CEA) and CEA-related cell adhesion molecule 1 (CEACAM1), apically expressed on human colonic M cells, are potential receptors for microbial adhesion. Histochem Cell Biol. 2004; 121:83-89. [PubMed: 14758482]

Barnich N, Carvalho FA, Glasser AL, Darcha C, Jantscheff P, Allez M, Peeters H, Bommelaer G, Desreumaux P, Colombel JF, et al. CEACAM6 acts as a receptor for adherent-invasive E. coli, supporting ileal mucosa colonization in Crohn disease. J Clin Invest. 2007; 117:1566-1574. [PubMed: 17525800]

Benson A, Pifer R, Behrendt CL, Hooper LV, Yarovinsky F. Gut commensal bacteria direct a protective immune response against Toxoplasma gondii. Cell Host Microbe. 2009; 6:187-196. [PubMed: 19683684]

Bouskra D, Brezillon C, Berard M, Werts C, Varona R, Boneca IG, Eberl G. Lymphoid tissue genesis induced by commensals through NOD1 regulates intestinal homeostasis. Nature. 2008; 456:507510. [PubMed: 18987631]

Bry L, Falk PG, Midtvedt T, Gordon JI. A model of host-microbial interactions in an open mammalian ecosystem. Science. 1996; 273:1380-1383. [PubMed: 8703071]

Carvalho FA, Barnich N, Sivignon A, Darcha C, Chan CH, Stanners CP, Darfeuille-Michaud A. Crohn's disease adherent-invasive Escherichia coli colonize and induce strong gut inflammation in transgenic mice expressing human CEACAM. J Exp Med. 2009; 206:2179-2189. [PubMed: 19737864]

Cash HL, Whitham CV, Behrendt CL, Hooper LV. Symbiotic bacteria direct expression of an intestinal bactericidal lectin. Science. 2006; 313:1126-1130. [PubMed: 16931762]

Cerdeno-Tarraga AM, Patrick S, Crossman LC, Blakely G, Abratt V, Lennard N, Poxton I, Duerden B, Harris B, Quail MA, et al. Extensive DNA inversions in the B. fragilis genome control variable gene expression. Science. 2005; 307:1463-1465. [PubMed: 15746427]

Chang DE, Smalley DJ, Tucker DL, Leatham MP, Norris WE, Stevenson SJ, Anderson AB, Grissom JE, Laux DC, Cohen PS, et al. Carbon nutrition of Escherichia coli in the mouse intestine. Proc Natl Acad Sci USA. 2004; 101:7427-7432. [PubMed: 15123798]

Cheesman SE, Guillemin K. We know you are in there: Conversing with the indigenous gut microbiota. Res Microbiol. 2007; 158:2-9. [PubMed: 17223317]

Chow J, Mazmanian SK. Getting the bugs out of the immune system: Do bacterial microbiota "fix" intestinal T cell responses? Cell Host Microbe. 2009; 5:8-12. [PubMed: 19154983] 
Christensen HR, Frokiaer H, Pestka JJ. Lactobacilli differentially modulate expression of cytokines and maturation surface markers in murine dendritic cells. J Immunol. 2002; 168:171-178. [PubMed: 11751960]

Chung DR, Kasper DL, Panzo RJ, Chtinis T, Grusby MJ, Sayegh MH, Tzianabos AO. CD4+ T cells mediate abscess formation in intra-abdominal sepsis by an IL-17-dependent mechanism. $\mathrm{J}$ Immunol. 2003; 170:1958-1963. [PubMed: 12574364]

Comstock LE, Coyne MJ. Bacteroides thetaiotaomicron: A dynamic, niche-adapted human symbiont. Bioessays. 2003; 25:926-929. [PubMed: 14505359]

Cong Y, Feng T, Fujihashi K, Schoeb TR, Elson CO. A dominant, coordinated T regulatory cell-IgA response to the intestinal microbiota. Proc Natl Acad Sci USA. 2009; 106:19256-19261. [PubMed: 19889972]

Curtis MM, Way SS. Interleukin-17 in host defence against bacterial, myco-bacterial and fungal pathogens. Immunology. 2009; 126:177-185. [PubMed: 19125888]

Deplancke B, Gaskins HR. Microbial modulation of innate defense: Goblet cells and the intestinal mucus layer. Am J Clin Nutr. 2001; 73:1131S-1141S. [PubMed: 11393191]

Dethlefsen L, McFall-Ngai M, Relman DA. An ecological and evolutionary perspective on humanmicrobe mutualism and disease. Nature. 2007; 449:811-818. [PubMed: 17943117]

Duerr RH, Taylor KD, Brant SR, Rioux JD, Silverberg MS, Daly MJ, Steinhart AH, Abraham C, Regueiro M, Griffiths A, et al. A genome-wide association study identifies IL23R as an inflammatory bowel disease gene. Science. 2006; 314:1461-1463. [PubMed: 17068223]

Eckburg PB, Bik EM, Bernstein CN, Purdom E, Dethlefsen L, Sargent M, Gill SR, Nelson KE, Relman DA. Diversity of the human intestinal microbial flora. Science. 2005; 308:1635-1638. [PubMed: 15831718]

Edwards D. The roles of tolerance in the evolution, maintenance and breakdown of mutualism. Naturwissenschaften. 2009; 96:1137-1145. [PubMed: 19484212]

Elson CO, Cong Y, Weaver CT, Schoeb TR, McClanahan TK, Fick RB, Kastelein RA. Monoclonal anti-interleukin 23 reverses active colitis in a T cell-mediated model in mice. Gastroenterology. 2007; 132:2359-2370. [PubMed: 17570211]

Erdman SE, Rao VP, Poutahidis T, Rogers AB, Taylor CL, Jackson EA, Ge Z, Lee CW, Schauer DB, Wogan GN, et al. Nitric oxide and TNF-alpha trigger colonic inflammation and carcinogenesis in Helicobacter hepaticus-infected, Rag2-deficient mice. Proc Natl Acad Sci USA. 2009; 106:10271032. [PubMed: 19164562]

Falk PG, Hooper LV, Midtvedt T, Gordon JI. Creating and maintaining the gastrointestinal ecosystem: What we know and need to know from gnotobiology. Microbiol Mol Biol Rev. 1998; 62:11571170. [PubMed: 9841668]

Fontenot JD, Rasmussen JP, Williams LM, Dooley JL, Farr AG, Rudensky AY. Regulatory T cell lineage specification by the forkhead transcription factor foxp3. Immunity. 2005; 22:329-341. [PubMed: 15780990]

Foster KR, Wenseleers T. A general model for the evolution of mutualisms. J Evol Biol. 2006; 19:1283-1293. [PubMed: 16780529]

Franchimont D, Vermeire S, El Housni H, Pierik M, Van Steen K, Gustot T, Quertinmont E, Abramowicz M, Van Gossum A, Deviere J, et al. Deficient host-bacteria interactions in inflammatory bowel disease? The toll-like receptor (TLR)-4 Asp299gly polymorphism is associated with Crohn's disease and ulcerative colitis. Gut. 2004; 53:987-992. [PubMed: 15194649]

Frank DN, St Amand AL, Feldman RA, Boedeker EC, Harpaz N, Pace NR. Molecular-phylogenetic characterization of microbial community imbalances in human inflammatory bowel diseases. Proc Natl Acad Sci USA. 2007; 104:13780-13785. [PubMed: 17699621]

Freitas M, Axelsson LG, Cayuela C, Midtvedt T, Trugnan G. Indigenous microbes and their soluble factors differentially modulate intestinal glycosylation steps in vivo. Use of a "lectin assay" to survey in vivo glycosylation changes. Histochem Cell Biol. 2005; 124:423-433. [PubMed: 16160839] 
Gaboriau-Routhiau V, Rakotobe S, Lecuyer E, Mulder I, Lan A, Bridonneau C, Rochet V, Pisi A, De Paepe M, Brandi G, et al. The key role of segmented filamentous bacteria in the coordinated maturation of gut helper T cell responses. Immunity. 2009; 31:677-689. [PubMed: 19833089]

Garrett WS, Lord GM, Punit S, Lugo-Villarino G, Mazmanian SK, Ito S, Glickman JN, Glimcher LH. Communicable ulcerative colitis induced by T-bet deficiency in the innate immune system. Cell. 2007; 131:33-45. [PubMed: 17923086]

Garrett WS, Punit S, Gallini CA, Michaud M, Zhang D, Sigrist KS, Lord GM, Glickman JN, Glimcher LH. Colitis-associated colorectal cancer driven by T-bet deficiency in dendritic cells. Cancer Cell. 2009; 16:208-219. [PubMed: 19732721]

Gibson FC III, Onderdonk AB, Kasper DL, Tzianabos AO. Cellular mechanism of intraabdominal abscess formation by Bacteroides fragilis. J Immunol. 1998; 160:5000-5006. [PubMed: 9590249]

Granato D, Bergonzelli GE, Pridmore RD, Marvin L, Rouvet M, Corthesy-Theulaz IE. Cell surfaceassociated elongation factor Tu mediates the attachment of Lactobacillus johnsonii NCC533 (La1) to human intestinal cells and mucins. Infect Immun. 2004; 72:2160-2169. [PubMed: 15039339]

Hall JA, Bouladoux N, Sun CM, Wohlfert EA, Blank RB, Zhu Q, Grigg ME, Berzofsky JA, Belkaid Y. Commensal DNA limits regulatory T cell conversion and is a natural adjuvant of intestinal immune responses. Immunity. 2008; 29:637-649. [PubMed: 18835196]

Hampe J, Cuthbert A, Croucher PJ, Mirza MM, Mascheretti S, Fisher S, Frenzel H, King K, Hasselmeyer A, MacPherson AJ, et al. Association between insertion mutation in NOD2 gene and Crohn's disease in German and British populations. Lancet. 2001; 357:1925-1928. [PubMed: 11425413]

Hampe J, Franke A, Rosenstiel P, Till A, Teuber M, Huse K, Albrecht M, Mayr G, De La Vega FM, Briggs J, et al. A genome-wide association scan of nonsynonymous SNPs identifies a susceptibility variant for Crohn disease in ATG16L1. Nat Genet. 2007; 39:207-211. [PubMed: 17200669]

Harig JM, Soergel KH, Komorowski RA, Wood CM. Treatment of diversion colitis with short-chainfatty acid irrigation. N Engl J Med. 1989; 320:23-28. [PubMed: 2909876]

Hegazy AN, Peine M, Helmstetter C, Panse I, Fröhlich A, Bergthaler A, Flatz L, Pinschewer DD, Radbruch A, Löhning M. Interferons direct Th2 cell reprogramming to generate a stable GATA-3+ T-bet+ cell subset with combined Th2 and Th1 cell functions. Immunity. 2010; 32:116128. [PubMed: 20079668]

Hooper LV. Do symbiotic bacteria subvert host immunity? Nat Rev Microbiol. 2009; 7:367-374. [PubMed: 19369952]

Hooper LV, Xu J, Falk PG, Midtvedt T, Gordon JI. A molecular sensor that allows a gut commensal to control its nutrient foundation in a competitive ecosystem. Proc Natl Acad Sci USA. 1999; 96:9833-9838. [PubMed: 10449780]

Hooper LV, Wong MH, Thelin A, Hansson L, Falk PG, Gordon JI. Molecular analysis of commensal host-microbial relationships in the intestine. Science. 2001; 291:881-884. [PubMed: 11157169]

Hooper LV, Midtvedt T, Gordon JI. How host-microbial interactions shape the nutrient environment of the mammalian intestine. Annu Rev Nutr. 2002; 22:283-307. [PubMed: 12055347]

Hooper LV, Stappenbeck TS, Hong CV, Gordon JI. Angiogenins: A new class of microbicidal proteins involved in innate immunity. Nat Immunol. 2003; 4:269-273. [PubMed: 12548285]

Hornef MW, Frisan T, Vandewalle A, Normark S, Richter-Dahlfors A. Toll-like receptor 4 resides in the Golgi apparatus and colocalizes with internalized lipopolysaccharide in intestinal epithelial cells. J Exp Med. 2002; 195:559-570. [PubMed: 11877479]

Hugot JP, Chamaillard M, Zouali H, Lesage S, Cezard JP, Belaiche J, Almer S, Tysk C, O’Morain CA, Gassull M, et al. Association of NOD2 leucine-rich repeat variants with susceptibility to Crohn's disease. Nature. 2001; 411:599-603. [PubMed: 11385576]

Ivanov II, Frutos Rde L, Manel N, Yoshinaga K, Rifkin DB, Sartor RB, Finlay BB, Littman DR. Specific microbiota direct the differentiation of IL-17-producing T-helper cells in the mucosa of the small intestine. Cell Host Microbe. 2008; 4:337-349. [PubMed: 18854238]

Ivanov II, Atarashi K, Manel N, Brodie EL, Shima T, Karaoz U, Wei D, Goldfarb KC, Santee CA, Lynch SV, et al. Induction of intestinal Th17 cells by segmented filamentous bacteria. Cell. 2009; 139:485-498. [PubMed: 19836068] 
Johansson ME, Phillipson M, Petersson J, Velcich A, Holm L, Hansson GC. The inner of the two Muc2 mucin-dependent mucus layers in colon is devoid of bacteria. Proc Natl Acad Sci USA. 2008; 105:15064-15069. [PubMed: 18806221]

Jonsson H, Strom E, Roos S. Addition of mucin to the growth medium triggers mucus-binding activity in different strains of Lactobacillus reuteri in vitro. FEMS Microbiol Lett. 2001; 204:19-22. [PubMed: 11682171]

Kanauchi O, Suga T, Tochihara M, Hibi T, Naganuma M, Homma T, Asakura H, Nakano H, Takahama K, Fujiyama Y, et al. Treatment of ulcerative colitis by feeding with germinated barley foodstuff: first report of a multicenter open control trial. J Gastroenterol. 2002; 37(Suppl 14):6772. [PubMed: 12572869]

Karin M, Ben-Neriah Y. Phosphorylation meets ubiquitination: The control of NF-[kappa]B activity. Annu Rev Immunol. 2000; 18:621-663. [PubMed: 10837071]

Kelly D, Campbell JI, King TP, Grant G, Jansson EA, Coutts AG, Pettersson S, Conway S. Commensal anaerobic gut bacteria attenuate inflammation by regulating nuclear-cytoplasmic shuttling of PPAR-gamma and RelA. Nat Immunol. 2004; 5:104-112. [PubMed: 14691478]

Kelly D, Conway S, Aminov R. Commensal gut bacteria: Mechanisms of immune modulation. Trends Immunol. 2005; 26:326-333. [PubMed: 15922949]

Kinross JM, von Roon AC, Holmes E, Darzi A, Nicholson JK. The human gut microbiome: Implications for future health care. Curr Gastroenterol Rep. 2008; 10:396-403. [PubMed: 18627653]

Korn T, Bettelli E, Oukka M, Kuchroo VK. IL-17 and Th17 cells. Annu Rev Immunol. 2009; 27:485517. [PubMed: 19132915]

Koropatnick TA, Engle JT, Apicella MA, Stabb EV, Goldman WE, McFall-Ngai MJ. Microbial factor-mediated development in a host-bacterial mutualism. Science. 2004; 306:1186-1188. [PubMed: 15539604]

Krinos CM, Coyne MJ, Weinacht KG, Tzianabos AO, Kasper DL, Comstock LE. Extensive surface diversity of a commensal microorganism by multiple DNA inversions. Nature. 2001; 414:555558. [PubMed: 11734857]

Kullberg MC. Bacteria-triggered CD4+ T regulatory cells suppress Helicobacter hepaticus-induced colitis. J Exp Med. 2002; 196:505-515. [PubMed: 12186842]

Kullberg MC, Ward JM, Gorelick PL, Caspar P, Hieny S, Cheever A, Jankovic D, Sher A. Helicobacter hepaticus triggers colitis in specific-pathogen-free interleukin-10 (IL-10)-deficient mice through an IL-12- and gamma interferon-dependent mechanism. Infect Immun. 1998; 66:5157-5166. [PubMed: 9784517]

Kullberg MC, Rothfuchs AG, Jankovic D, Caspar P, Wynn TA, Gorelick PL, Cheever AW, Sher A. Helicobacter hepaticus-induced colitis in interleukin-10-deficient mice: Cytokine requirements for the induction and maintenance of intestinal inflammation. Infect Immun. 2001; 69:4232-4241. [PubMed: 11401959]

Kullberg MC, Andersen JF, Gorelick PL, Caspar P, Suerbaum S, Fox JG, Cheever AW, Jankovic D, Sher A. Induction of colitis by a CD4+ T cell clone specific for a bacterial epitope. Proc Natl Acad Sci USA. 2003; 100:15830-15835. [PubMed: 14673119]

Lai Y, Di Nardo A, Nakatsuji T, Leichtle A, Yang Y, Cogen AL, Wu ZR, Hooper LV, Schmidt RR, von Aulock S, et al. Commensal bacteria regulate Toll-like receptor 3-dependent inflammation after skin injury. Nat Med. 2009; 15:1377-1382. [PubMed: 19966777]

Lee YK, Turner H, Maynard CL, Oliver JR, Chen D, Elson CO, Weaver CT. Late developmental plasticity in the T helper 17 lineage. Immunity. 2009; 30:92-107. [PubMed: 19119024]

Ley RE, Peterson DA, Gordon JI. Ecological and evolutionary forces shaping microbial diversity in the human intestine. Cell. 2006; 124:837-848. [PubMed: 16497592]

Ley RE, Knight R, Gordon JI. The human microbiome: Eliminating the biomedical/environmental dichotomy in microbial ecology. Environ Microbiol. 2007; 9:3-4. [PubMed: 17227400]

Lievin-Le Moal V, Servin AL. The front line of enteric host defense against unwelcome intrusion of harmful microorganisms: Mucins, antimicrobial peptides, and microbiota. Clin Microbiol Rev. 2006; 19:315-337. [PubMed: 16614252] 
Macpherson AJ, Harris NL. Interactions between commensal intestinal bacteria and the immune system. Nat Rev Immunol. 2004; 4:478-485. [PubMed: 15173836]

Macpherson AJ, Uhr T. Induction of protective IgA by intestinal dendritic cells carrying commensal bacteria. Science. 2004; 303:1662-1665. [PubMed: 15016999]

Macpherson A, Khoo UY, Forgacs I, Philpott-Howard J, Bjarnason I. Mucosal antibodies in inflammatory bowel disease are directed against intestinal bacteria. Gut. 1996; 38:365-375. [PubMed: 8675088]

Macpherson AJ, Gatto D, Sainsbury E, Harriman GR, Hengartner H, Zinkernagel RM. A primitive T cell-independent mechanism of intestinal mucosal IgA responses to commensal bacteria. Science. 2000; 288:2222-2226. [PubMed: 10864873]

Macpherson AJ, Hunziker L, McCoy K, Lamarre A. IgA responses in the intestinal mucosa against pathogenic and non-pathogenic microorganisms. Microbes Infect. 2001; 3:1021-1035. [PubMed: 11580989]

Martens EC, Koropatkin NM, Smith TJ, Gordon JI. Complex glycan catabolism by the human gut microbiota: The Bacteroidetes Sus-like paradigm. J Biol Chem. 2009; 284:24673-24677. [PubMed: 19553672]

Maslowski KM, Vieira AT, Ng A, Kranich J, Sierro F, Yu D, Schilter HC, Rolph MS, Mackay F, Artis $\mathrm{D}$, et al. Regulation of inflammatory responses by gut microbiota and chemoattractant receptor GPR43. Nature. 2009; 461:1282-1286. [PubMed: 19865172]

Matsuo K, Ota H, Akamatsu T, Sugiyama A, Katsuyama T. Histochemistry of the surface mucous gel layer of the human colon. Gut. 1997; 40:782-789. [PubMed: 9245933]

Mazmanian SK, Liu CH, Tzianabos AO, Kasper DL. An immunomodulatory molecule of symbiotic bacteria directs maturation of the host immune system. Cell. 2005; 122:107-118. [PubMed: 16009137]

Mazmanian SK, Round JL, Kasper DL. A microbial symbiosis factor prevents intestinal inflammatory disease. Nature. 2008; 453:620-625. [PubMed: 18509436]

McCormick BA, Stocker BA, Laux DC, Cohen PS. Roles of motility, chemotaxis, and penetration through and growth in intestinal mucus in the ability of an avirulent strain of Salmonella typhimurium to colonize the large intestine of streptomycin-treated mice. Infect Immun. 1988; 56:2209-2217. [PubMed: 3044995]

Murai M, Turovskaya O, Kim G, Madan R, Karp CL, Cheroutre H, Kronenberg M. Interleukin 10 acts on regulatory $\mathrm{T}$ cells to maintain expression of the transcription factor Foxp3 and suppressive function in mice with colitis. Nat Immunol. 2009; 10:1178-1184. [PubMed: 19783988]

Neish AS, Gewirtz AT, Zeng H, Young AN, Hobert ME, Karmali V, Rao AS, Madara JL. Prokaryotic regulation of epithelial responses by inhibition of IkappaB-alpha ubiquitination. Science. 2000; 289:1560-1563. [PubMed: 10968793]

Niess JH, Leithauser F, Adler G, Reimann J. Commensal gut flora drives the expansion of proinflammatory CD4 $\mathrm{T}$ cells in the colonic lamina propria under normal and inflammatory conditions. J Immunol. 2008; 180:559-568. [PubMed: 18097058]

Nowak MA. Five rules for the evolution of cooperation. Science. 2006; 314:1560-1563. [PubMed: 17158317]

Nyholm SV, McFall-Ngai MJ. Dominance of Vibrio fischeri in secreted mucus outside the light organ of Euprymna scolopes: The first site of symbiont specificity. Appl Environ Microbiol. 2003; 69:3932-3937. [PubMed: 12839763]

Nyholm SV, McFall-Ngai MJ. The winnowing: Establishing the squid-vibrio symbiosis. Nat Rev Microbiol. 2004; 2:632-642. [PubMed: 15263898]

O'Hara AM, Shanahan F. The gut flora as a forgotten organ. EMBO Rep. 2006; 7:688-693. [PubMed: 16819463]

O’Mahony C, Scully P, O’Mahony D, Murphy S, O’Brien F, Lyons A, Sherlock G, MacSharry J, Kiely B, Shanahan F, et al. Commensal-induced regulatory $\mathrm{T}$ cells mediate protection against pathogen-stimulated NF-kappaB activation. PLoS Pathog. 2008; 4:e1000112. [PubMed: 18670628] 
Ogura Y, Bonen DK, Inohara N, Nicolae DL, Chen FF, Ramos R, Britton H, Moran T, Karaliuskas R, Duerr RH, et al. A frameshift mutation in NOD2 associated with susceptibility to Crohn's disease. Nature. 2001; 411:603-606. [PubMed: 11385577]

Ortega-Cava CF, Ishihara S, Rumi MA, Kawashima K, Ishimura N, Kazumori H, Udagawa J, Kadowaki Y, Kinoshita Y. Strategic compartmentalization of Toll-like receptor 4 in the mouse gut. J Immunol. 2003; 170:3977-3985. [PubMed: 12682225]

Packey CD, Sartor RB. Interplay of commensal and pathogenic bacteria, genetic mutations, and immunoregulatory defects in the pathogenesis of inflammatory bowel diseases. J Intern Med. 2008; 263:597-606. [PubMed: 18479259]

Palmer C, Bik EM, DiGiulio DB, Relman DA, Brown PO. Development of the human infant intestinal microbiota. PLoS Biol. 2007; 5:e177. [PubMed: 17594176]

Pamer EG. Immune responses to commensal and environmental microbes. Nat Immunol. 2007; 8:1173-1178. [PubMed: 17952042]

Perru O. Cooperation strategies, signals and symbiosis. C R Biol. 2006; 329:928-937. [PubMed: 17126796]

Peterson DA, McNulty NP, Guruge JL, Gordon JI. IgA response to symbiotic bacteria as a mediator of gut homeostasis. Cell Host Microbe. 2007; 2:328-339. [PubMed: 18005754]

Pierik M, Joossens S, Van Steen K, Van Schuerbeek N, Vlietinck R, Rutgeerts P, Vermeire S. Tolllike receptor-1, -2 , and -6 polymorphisms influence disease extension in inflammatory bowel diseases. Inflamm Bowel Dis. 2006; 12:1-8. [PubMed: 16374251]

Rakoff-Nahoum S, Paglino J, Eslami-Varzaneh F, Edberg S, Medzhitov R. Recognition of commensal microflora by toll-like receptors is required for intestinal homeostasis. Cell. 2004; 118:229-241. [PubMed: 15260992]

Rioux JD, Xavier RJ, Taylor KD, Silverberg MS, Goyette P, Huett A, Green T, Kuballa P, Barmada MM, Datta LW, et al. Genome-wide association study identifies new susceptibility loci for Crohn disease and implicates autophagy in disease pathogenesis. Nat Genet. 2007; 39:596-604. [PubMed: 17435756]

Robbe C, Capon C, Maes E, Rousset M, Zweibaum A, Zanetta JP, Michalski JC. Evidence of regiospecific glycosylation in human intestinal mucins: Presence of an acidic gradient along the intestinal tract. J Biol Chem. 2003; 278:46337-46348. [PubMed: 12952970]

Round JL, Mazmanian SK. The gut microbiota shapes intestinal immune responses during health and disease. Nat Rev Immunol. 2009; 9:313-323. [PubMed: 19343057]

Ryu JH, Kim SH, Lee HY, Bai JY, Nam YD, Bae JW, Lee DG, Shin SC, Ha EM, Lee WJ. Innate immune homeostasis by the homeobox gene caudal and commensal-gut mutualism in Drosophila. Science. 2008; 319:777-782. [PubMed: 18218863]

Salzman NH, Underwood MA, Bevins CL. Paneth cells, defensins, and the commensal microbiota: A hypothesis on intimate interplay at the intestinal mucosa. Semin Immunol. 2007; 19:70-83. [PubMed: 17485224]

Salzman NH, Hung K, Haribhai D, Chu H, Karlsson-Sjoberg J, Amir E, Teggatz P, Barman M, Hayward M, Eastwood D, et al. Enteric defensins are essential regulators of intestinal microbial ecology. Nat Immunol. 2010; 11:76-83. [PubMed: 19855381]

Sanos SL, Bui VL, Mortha A, Oberle K, Heners C, Johner C, Diefenbach A. RORgammat and commensal microflora are required for the differentiation of mucosal interleukin 22-producing NKp46+ cells. Nat Immunol. 2009; 10:83-91. [PubMed: 19029903]

Sansonetti PJ. War and peace at mucosal surfaces. Nat Rev Immunol. 2004; 4:953-964. [PubMed: 15573130]

Sartor RB. Therapeutic manipulation of the enteric microflora in inflammatory bowel diseases: Antibiotics, probiotics, and prebiotics. Gastroenterology. 2004; 126:1620-1633. [PubMed: 15168372]

Scanlan PD, Shanahan F, O’Mahony C, Marchesi JR. Culture-independent analyses of temporal variation of the dominant fecal microbiota and targeted bacterial subgroups in Crohn's disease. J Clin Microbiol. 2006; 44:3980-3988. [PubMed: 16988018]

Schmechel S, Konrad A, Diegelmann J, Glas J, Wetzke M, Paschos E, Lohse P, Goke B, Brand S. Linking genetic susceptibility to Crohn's disease with Th17 cell function: IL-22 serum levels are 
increased in Crohn's disease and correlate with disease activity and IL23R genotype status. Inflamm Bowel Dis. 2008; 14:204-212. [PubMed: 18022867]

Smith K, McCoy KD, Macpherson AJ. Use of axenic animals in studying the adaptation of mammals to their commensal intestinal microbiota. Semin Immunol. 2007; 19:59-69. [PubMed: 17118672]

Sokol H, Pigneur B, Watterlot L, Lakhdari O, Bermudez-Humaran LG, Gratadoux JJ, Blugeon S, Bridonneau C, Furet JP, Corthier G, et al. Faecalibacterium prausnitzii is an anti-inflammatory commensal bacterium identified by gut microbiota analysis of Crohn disease patients. Proc Natl Acad Sci USA. 2008; 105:16731-16736. [PubMed: 18936492]

Sonnenburg JL, Angenent LT, Gordon JI. Getting a grip on things: How do communities of bacterial symbionts become established in our intestine? Nat Immunol. 2004; 5:569-573. [PubMed: 15164016]

Sonnenburg JL, Xu J, Leip DD, Chen CH, Westover BP, Weatherford J, Buhler JD, Gordon JI. Glycan foraging in vivo by an intestine-adapted bacterial symbiont. Science. 2005; 307:1955-1959. [PubMed: 15790854]

Stappenbeck TS, Hooper LV, Gordon JI. Developmental regulation of intestinal angiogenesis by indigenous microbes via Paneth cells. Proc Natl Acad Sci USA. 2002; 99:15451-15455. [PubMed: 12432102]

Suzuki K, Meek B, Doi Y, Muramatsu M, Chiba T, Honjo T, Fagarasan S. Aberrant expansion of segmented filamentous bacteria in IgA-deficient gut. Proc Natl Acad Sci USA. 2004; 101:19811986. [PubMed: 14766966]

Swidsinski A, Ladhoff A, Pernthaler A, Swidsinski S, Loening-Baucke V, Ortner M, Weber J, Hoffmann U, Schreiber S, Dietel M, et al. Mucosal flora in inflammatory bowel disease. Gastroenterology. 2002; 122:44-54. [PubMed: 11781279]

Takeda K, Akira S. Toll-like receptors in innate immunity. Int Immunol. 2005; 17:1-14. [PubMed: 15585605]

Tanabe S, Kinuta Y, Saito Y. Bifidobacterium infantis suppresses proinflammatory interleukin-17 production in murine splenocytes and dextran sodium sulfate-induced intestinal inflammation. Int J Mol Med. 2008; 22:181-185. [PubMed: 18636171]

Taylor PD, Day T, Nagy D, Wild G, André JB, Gardner A. The evolutionary consequences of plasticity in host-pathogen interactions. Theor Popul Biol. 2006; 69:323-331. [PubMed: 16469343]

Timmerman CP, Mattsson E, Martinez-Martinez L, De Graaf L, Van Strijp JA, Verbrugh HA, Verhoef J, Fleer A. Induction of release of tumor necrosis factor from human monocytes by staphylococci and staphylococcal peptidoglycans. Infect Immun. 1993; 61:4167-4172. [PubMed: 8406805]

Treem WR, Ahsan N, Shoup M, Hyams JS. Fecal short-chain fatty acids in children with inflammatory bowel disease. J Pediatr Gastroenterol Nutr. 1994; 18:159-164. [PubMed: 8014762]

Turnbaugh PJ, Ley RE, Mahowald MA, Magrini V, Mardis ER, Gordon JI. An obesity-associated gut microbiome with increased capacity for energy harvest. Nature. 2006; 444:1027-1031. [PubMed: 17183312]

Turnbaugh PJ, Ley RE, Hamady M, Fraser-Liggett CM, Knight R, Gordon JI. The human microbiome project. Nature. 2007; 449:804-810. [PubMed: 17943116]

Ulvestad E. Cooperation and conflict in host-microbe relations. APMIS. 2009; 117:311-322. [PubMed: 19400859]

van Baalen M. Coevolution of recovery ability and virulence. Proc Biol Sci. 1998; 265:317-325. [PubMed: 9523434]

Vignali DA, Collison LW, Workman CJ. How regulatory T cells work. Nat Rev Immunol. 2008; 8:523-532. [PubMed: 18566595]

Vijay-Kumar M, Aitken JD, Carvalho FA, Cullender TC, Mwangi S, Srinivasan S, Sitaraman SV, Knight R, Ley RE, Gewirtz AT. Metabolic syndrome and altered gut microbiota in mice lacking toll-like receptor 5. Science. 2010; 328:228-231. [PubMed: 20203013]

Wehkamp J, Salzman NH, Porter E, Nuding S, Weichenthal M, Petras RE, Shen B, Schaeffeler E, Schwab M, Linzmeier R, et al. Reduced Paneth cell alpha-defensins in ileal Crohn's disease. Proc Natl Acad Sci USA. 2005; 102:18129-18134. [PubMed: 16330776] 
Whitman WB, Coleman DC, Wiebe WJ. Prokaryotes: the unseen majority. Proc Natl Acad Sci USA. 1998; 95:6578-6583. [PubMed: 9618454]

Xiao H, Gulen MF, Qin J, Yao J, Bulek K, Kish D, Altuntas CZ, Wald D, Ma C, Zhou H, et al. The Toll-interleukin-1 receptor member SIGIRR regulates colonic epithelial homeostasis, inflammation, and tumorigenesis. Immunity. 2007; 26:461-475. [PubMed: 17398123]

Xu J, Gordon JI. Inaugural article: Honor thy symbionts. Proc Natl Acad Sci USA. 2003; 100:1045210459. [PubMed: 12923294]

Xu J, Bjursell MK, Himrod J, Deng S, Carmichael LK, Chiang HC, Hooper LV, Gordon JI. A genomic view of the human-Bacteroides thetaiotaomicron symbiosis. Science. 2003; 299:20742076. [PubMed: 12663928]

Xu J, Mahowald MA, Ley RE, Lozupone CA, Hamady M, Martens EC, Henrissat B, Coutinho PM, Minx P, Latreille P, et al. Evolution of symbiotic bacteria in the distal human intestine. PLoS Biol. 2007; 5:e156. [PubMed: 17579514]

Yoshioka M, Fukuishi N, Iriguchi S, Ohsaki K, Yamanobe H, Inukai A, Kurihara D, Imajo N, Yasui Y, Matsui N, et al. Lipoteichoic acid downregulates FcepsilonRI expression on human mast cells through Toll-like receptor 2. J Allergy Clin Immunol. 2007; 120:452-461. [PubMed: 17481719]

Zhou X, Bailey-Bucktrout SL, Jeker LT, Penaranda C, Martinez-Llordella M, Ashby M, Nakayama M, Rosenthal W, Bluestone JA. Instability of the transcription factor Foxp3 leads to the generation of pathogenic memory T cells in vivo. Nat Immunol. 2009; 10:1000-1007. [PubMed: 19633673]

Zoetendal EG, von Wright A, Vilpponen-Salmela T, Ben-Amor K, Akkermans AD, de Vos WM.

Mucosa-associated bacteria in the human gastrointestinal tract are uniformly distributed along the colon and differ from the community recovered from feces. Appl Environ Microbiol. 2002;

68:3401-3407. [PubMed: 12089021] 